\title{
Fast scanning pyrometer for temperature measurements of car wheels
}

\author{
by M. Kastek, H. Madura, H. Polakowski and S. Sulej
}

Military University of Technology, 2 S. Kaliski St. 01-489 Warsaw, Poland

\begin{abstract}
The paper presents design and technical parameters of fast infrared pyrometer the measuring head of which can be shifted in relation to a measured object. Spectral range of the pyrometer operation is within 8-12 $\mu \mathrm{m}$. Measurements control and data registration are performed using adequate software. The pyrometer was used for measurement of temperature of moving car wheels.
\end{abstract}

\section{Introduction}

With motorization development the construction of car tyres has changed too [1]. Here are used the tyres of a new type which must be tested under conditions as near as possible to the real ones. One of the factors that enable us to evaluate both technical state of a tyre and its quality is the temperature distribution on its surface [2-4].

IR cameras were mostly used for this purpose. However, measurement with IR camera needs stoppage of wheels what disturbs thermal conditions on tyre surface. The results of such measurement include significant errors.

Due to wheel symmetry, information on temperature distribution on a tyre surface can be achieved on the basis of temperature distribution for one tyre's section. For dynamic measurements of rotating tyres the fast scanning pyrometers with a photon detector operating within the range of 8-12 $\mu \mathrm{m}$ were used.

\section{Design of a fast IR pyrometer}

The compound elements of a fast IR pyrometer (Fig.1) are measuring head, positioning system and electronic systems, computer controller.

The measuring head (1) is used for conversion of IR radiation emitted by a tyre surface into a corresponding voltage value, which is proportional to an object temperature. The measuring head incorporates a radiometric system (an objective with a germanium lens, thermoelectrically cooled photon IR detector with a preamplifier), laser indicators of a measured area and positioning system (regulation in a vertical position by the angle of $\pm 45^{\circ}$ ).

The positioning system and electronic system (2) enable movement of the measuring head in a horizontal direction at the distance up to $400 \mathrm{~mm}$ with the resolution of $0.1 \mathrm{~mm}$. In addition, the system includes electronic components (power supplies, controllers of a stepping motor, synchronisation units).

The computer controller (3) consists of IBM PC computer equipped with analogue-digital converter and interface card with an operating system of the pyrometer. Special software for the pyrometer, in addition to temperature registration, enables also measurement of tyre rotation velocity and automatically chooses the sampling rate.

A picture of the fast pyrometer is shown in Fig.2.

\section{Technical parameters of the pyrometer}

The pyrometer ensures remote control recording of a surface temperature of an object moving with the velocity of $250 \mathrm{~km} / \mathrm{h}$. The dimensions of a measuring area, at the distance of $1 \mathrm{~m}$, are $5 \times 5 \mathrm{~mm}$ and the distances between the consecutive measurement areas are $3 \mathrm{~mm}$. One measuring cycle comprises 1000 measurements and automatically chosen sampling 
http://dx.doi.org/10.21611/qirt.1998.053

period depends on the object's speed. Measuring range of the pyrometer is $20-300^{\circ} \mathrm{C}$ with the resolution of $0.50^{\circ} \mathrm{C}$ and its operating temperature is $5-30^{\circ} \mathrm{C}$. The measuring area is illuminated with a laser diode working on the wavelength of $670 \mathrm{~nm}$ and the cycle start is marked by an optoelectronic sensor.

\section{Measuring stands}

The applied design of the fast IR pyrometer enables measurements of temperature distribution on a tyre surface at two measuring stands. At Stand I (Fig. 3) a tyre is rolled along internal surface of a cylinder of $8 \mathrm{~m}$ diameter and there is a possibility of regulation of tyre static load. The examined tyre surface is seen periodically in the pyrometer field of view. Synchronisation of a temperature measurement with the rotation of the examined tyre ensures an optoelectronic non-contact proximity detector.

Positions of the measuring points on a tyre surface and the example of the registered temperature profile are shown in Fig.4.

At Stand II (Fig.5) a tyre (1) rotation is forced by a drum rotation (5) while a vehicle (car) is immovable. Measurement of a tyre temperature can be performed from a side of a tyre tread (as in Fig.5) or from a tyre side. Between the successive temperature measurements the pyrometer head is automatically shifted by means of a positioning system (according to the given programme).

\section{Measurement results}

The described fast IR pyrometer determines temperature of a tyre surface on the basis of the value of electrical signal from radiometric head with simultaneous consideration of an ambient temperature. Relation between these values has been experimentally determined using the standard sources of infrared radiation.

For pyrometer calibration within the measuring range of $20-70^{\circ} \mathrm{C}$ the Differential infrared Reference Source DCN 100 of the HGH Systemes Infrarouges Massy and within the range $70-300^{\circ} \mathrm{C}$ the $\mathrm{M} 360$ source of the Mikron Instrument Company, Inc. was applied.

Relation between the registered voltage (U) from a radiometric head and temperature of the investigated object ( $T$ ) and the ambient temperature (TO) is described by the relationship:

$$
\mathrm{T}=\mathrm{T} 0+\mathrm{U}(\mathrm{a} 1+\mathrm{U}(\mathrm{a} 2+\mathrm{U}(\mathrm{a} 3+\mathrm{a} 4 \mathrm{U})))
$$

where the a1, a2, a3, a4 coefficients are the numbers determined experimentally.

Temperature distribution on a surface of a tyre rolled for 15 minutes and with the velocity of $120 \mathrm{~km} / \mathrm{h}$ (Stand I) is illustrated in Fig.4. The measurements carried out for various velocities and various times of tyre rolling motion enable determination of temperature changes as a function of tyre velocity (Fig.6) for the measuring point corresponding to the temperature T1 (Fig.4).

\section{Conclusions}

A dynamic method of temperature measurement of external surface of tyres using fast IR pyrometer is characterised by many advantages in comparison with thermovision methods. Temperature registration is carried out during a tyre motion, so measurement results are significantly much more reliable than results obtained with IR camera for stopped (immovable) objects. On the basis of temperature distributions one can estimate adequate exploitation parameters of a tyre such as nominal static load and pressure inside a tyre.

\section{REFERENCES}

[1] KEVIN (J.) - Tire materials and construction. Automotive Engineering, October/1992.

[2] $\mathrm{OH}$ (B. S), KIM (Y. N), MOON (H. Y) and PARK (H. W) - Internal temperature distribution in a rolling tire, Tire Science Technology, Vol. 23, no 1, 1995. 
[3] EJSMONT (J. A.), TARYMA (S.), MIODUSZEWSKI (P.), WOŹNIAK (R.), WILGA (M.) Rozkład temperatury na zewnętrznej powierzchni opony samochodowej będącej w ruchu, Konferencja Naukowo-Techniczna nt. Rozwijanie Konstrukcji Samochodów „AUTOPROGRES" 1995.

[4] DEHNERT, VOLK - Brechnung der temperaturverteilung im rollenden reifen mitteles der methode der finiten elemente, Kautschuk+Gummmi-Kunststoffe no 1, 1992.
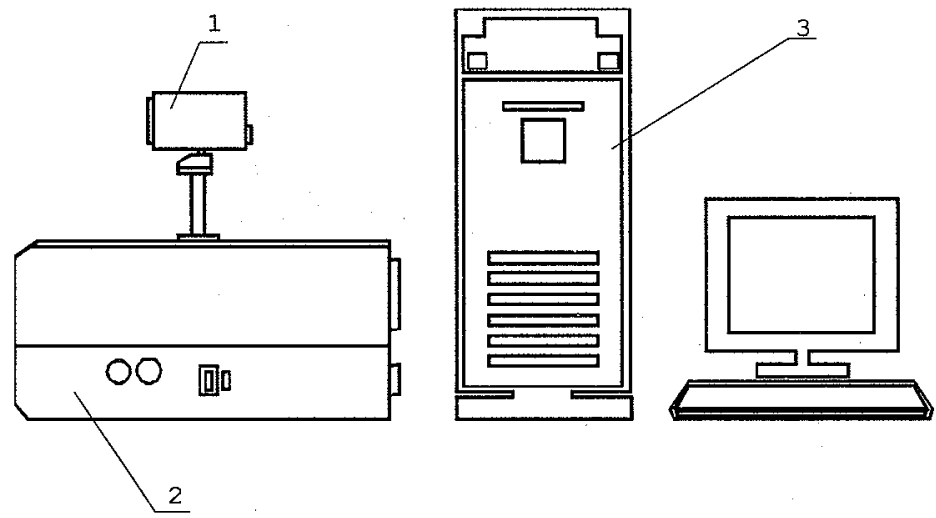

Fig. 1. Elements of a fast IR pyrometer; 1 - measuring head, 2 - positioning system and electronic system, 3 - computer controller

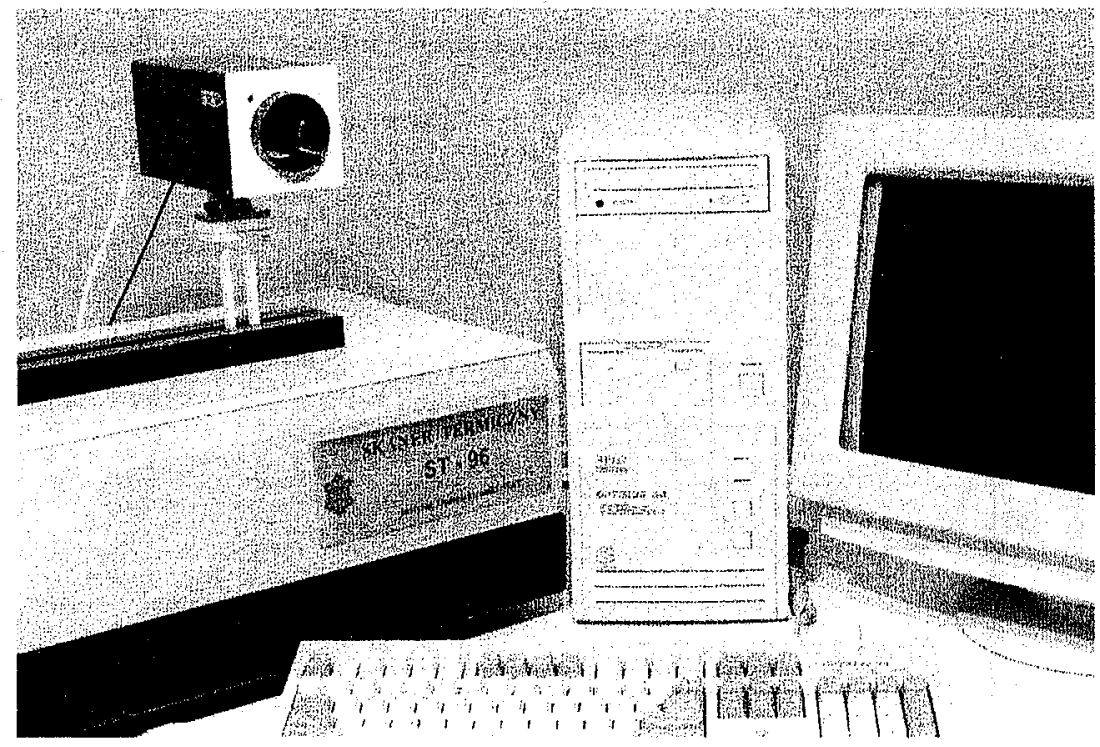

Fig. 2. Fast scanning pyrometer for temperature measurements of car wheels 
http://dx.doi.org/10.21611/qirt.1998.053

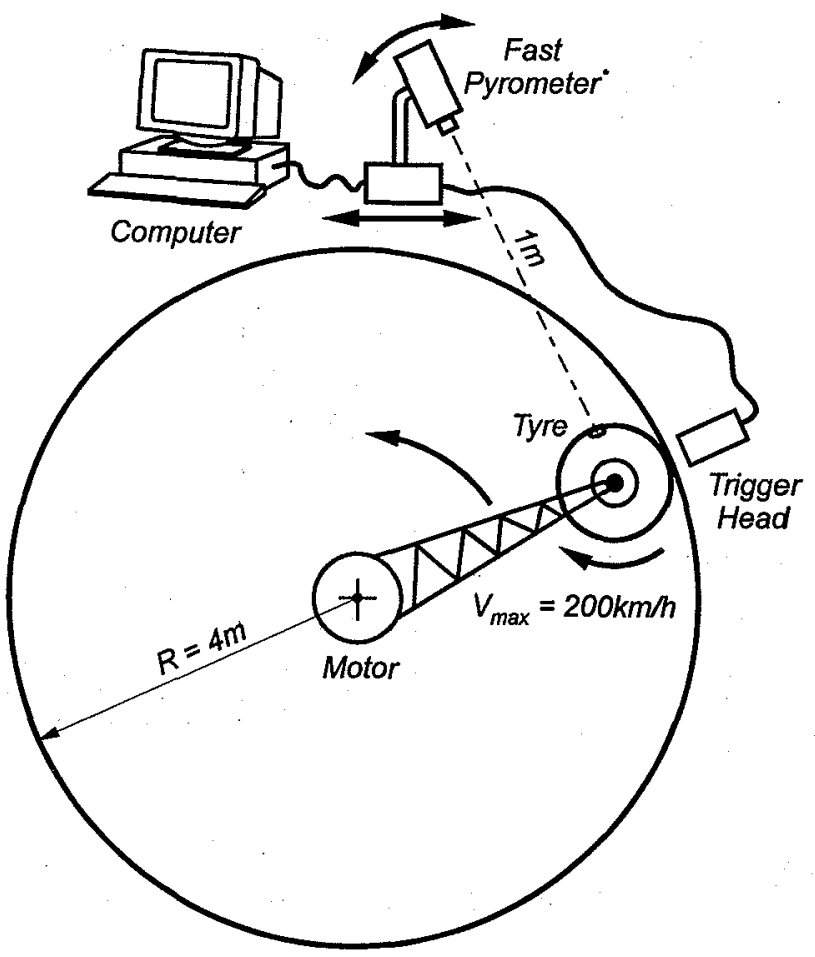

Fig. 3. Diagram of diagnostic stand used for car wheels testing (Stand I)

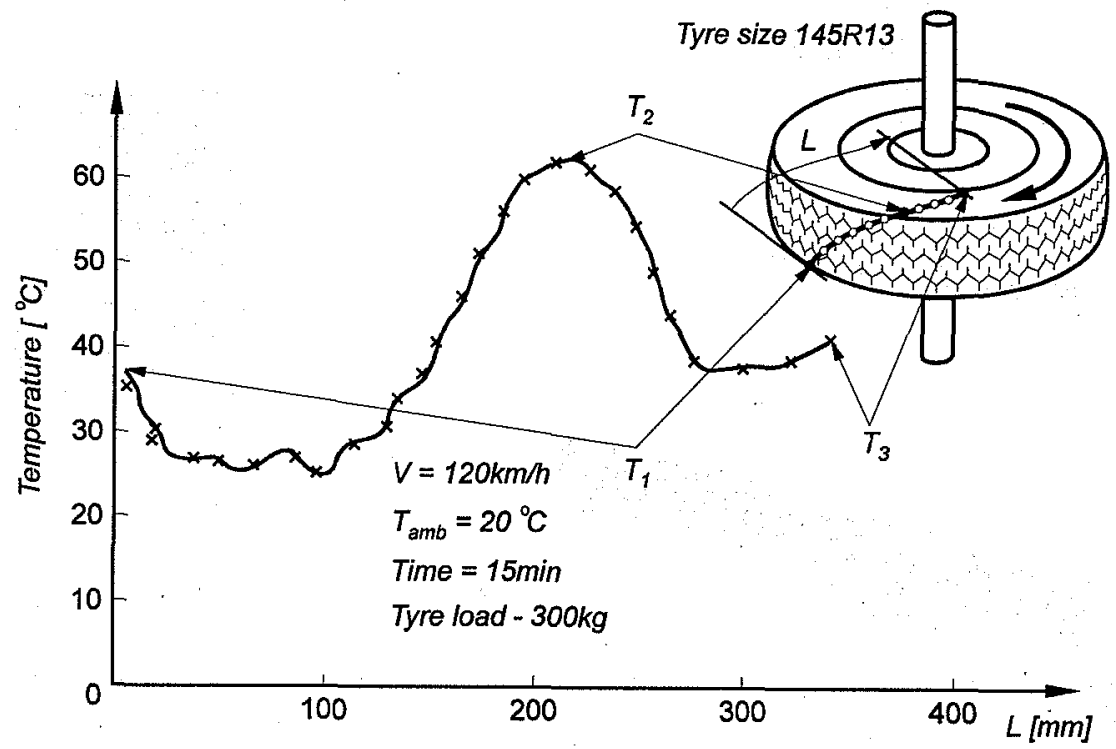

Fig. 4. Temperature distribution on car wheel surface 
http://dx.doi.org/10.21611/qirt.1998.053

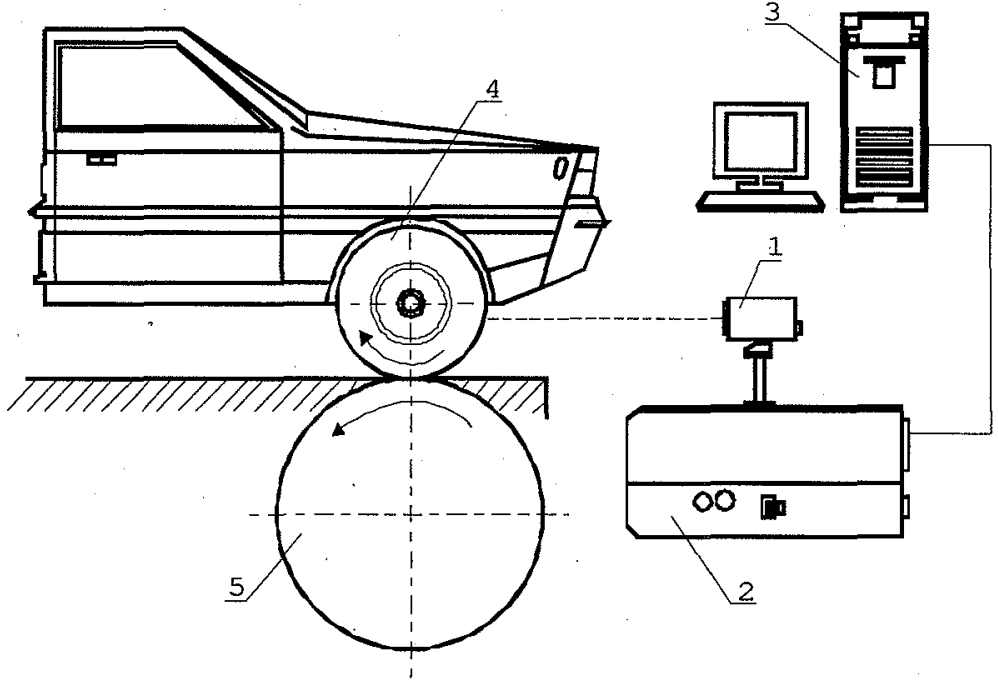

Fig. 5. Diagram of diagnostic stand used for car wheels testing (Stand II): 1- the measuring head, 2- the positioning system and electronic system, 3- the computer controller, 4-the tyre under testing, 5- the rotating drum

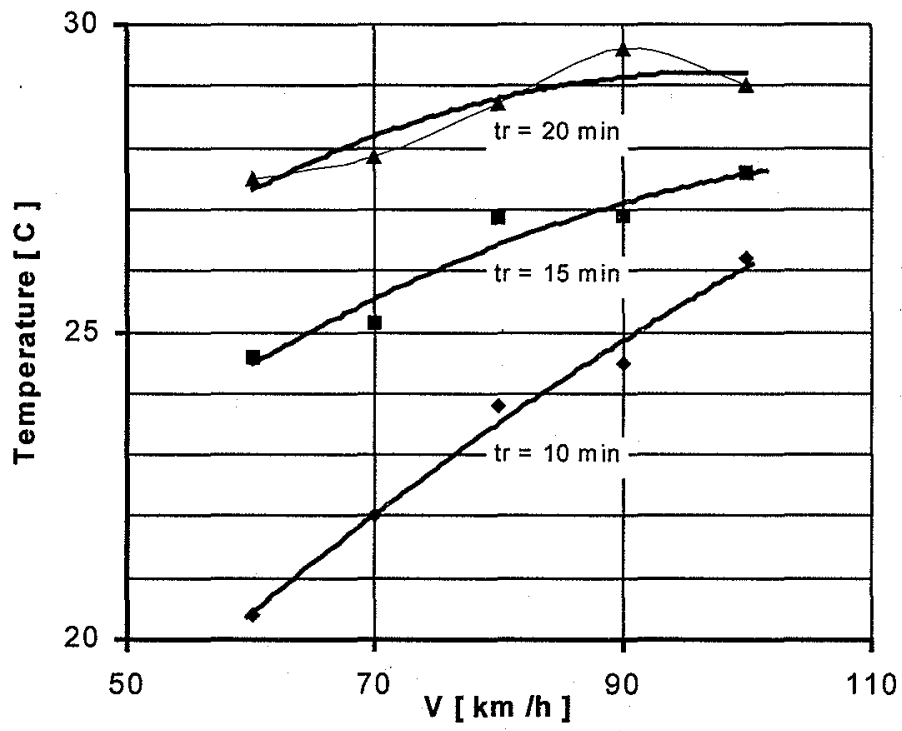

Fig. 6. Temperature distribution as a function of tyre velocity (tyre 145R13 under 250 $\mathrm{kg}$ load, $\mathrm{T}_{\mathrm{amb}}=18^{\circ} \mathrm{C}$ ): tr-time of tyre rolling 